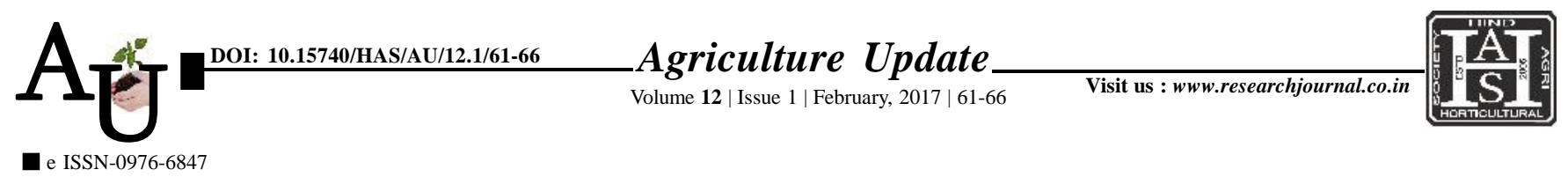

\title{
Research Article: Association between selected personal variables of the respondents with their level of adoption of improved rice production technology by the farmers in Dungarpur district of Rajasthan
}

Article Chronicle : Received :

25.11.2016;

Revised :

17.12.2016;

Accepted :

25.12.2016

\section{KeY WoRDS:}

Improved rice

production, Economic

motivation,

Cosmopolitan outlook

Author for correspondence :

RAM LAL KHATIK

Department of Extension Education, Rajasthan College of Agriculture, UDAIPUR (RAJASTHAN) INDIA

See end of the article for authors' affiliations
SUMMARY : India is the second leading producer of rice in the entire world, preceded by China. Rice remains a staple food for the majority of the world's population. More than two-thirds of the world relies on the nutritional benefits of rice. Rice is naturally fat, cholesterol and sodium free. It is a complex carbohydrate containing only 103 calories per one half- cup serving. Rice is primarily a high energy or high calorie food. It contains less protein than wheat. The protein content of rice is usually 6 to 7 per cent. In Rajasthan rice is grown on an area of 131126 Lakh hectares with a production of 265545 lakh tones (Anonymous, 2010-11). The major rice growing districts in Rajasthan are Banswara, Dungarpur, Kota, Bundi, Sriganganagar and Hanumangarh. The present study was conducted in Dungarpur district of Southern Rajasthan. There are total four tehsils in Dungarpur district of Rajasthan, out of which two tehsil namely Simalwara and Dungarpur have been selected on the basis of maximum area under cultivation of rice. Five villages from each identified tehsil were selected on the basis of maximum area under rice cultivation. Thus, in all 10 villages were selected for present investigation. For selection of respondents total 120 rice growers (60 small and 60 marginal farmers) were selected on the basis of random sampling method from the identified villages for the present study. It was found that personal characteristics viz., age, education, family income, size of land holding, extension contacts, cosmopolitan outlook and economic motivation were not significantly associated with adoption of improved rice production technology. It means that there was no effect of these personal variables on adoption of improved rice production technology.

How to cite this article : Khatik, Ram Lal and Bhimawat, B.S. (2017). Association between selected personal variables of the respondents with their level of adoption of improved rice production technology by the farmers in Dungarpur district of Rajasthan. Agric. Update, 12(1): 61-66; DOI : 10.15740/HAS/AU/12.1/61-66. 